\title{
Biomass for industrial applications: the role of torrefaction
}

Authors:

Svetlana Proskurina*, Lappeenranta University of Technology, Skinnarilankatu 34, 53850 Lappeenranta, Finland svetlana.proskurina@lut.fi

Jussi Heinimö, Mikkeli Development Miksei Ltd, Sammonkatu 12, 50130 Mikkeli, Finland jussi.heinimo@mikseimikkeli.fi

Fabian Schipfer, Technische Universität Wien, Gusshausstrasse 25/370-3, A-1040 Wien, Austria schipfer@eeg.tuwien.ac.at

Esa Vakkilainen, Lappeenranta University of Technology, Skinnarilankatu 34, 53850 Lappeenranta, Finland esa.vakkilainen@lut.fi

*Corresponding Author. Tel.:+358 466322953.

\begin{abstract}
Torrefied biomass has considerable potential as a biomass fuel to replace coal in energy and process heat production. The aim of this paper is to evaluate the potential of torrefied biomass in different industries, both power and non-power generation industries, and considers the impact of such use on the international biomass market. The power generation sector has been so far the leader in testing torrefied biomass use with other industrial demand lagging behind. There are promising technical possibilities for greater torrefied biomass use in a number of other areas such as the steel, non-metallic minerals, as well as the pulp and paper industries. Although a large increase in torrefied biomass consumption by industry is not immediately foreseeable, industrial use by actors outside the energy generation sector could increase demand for torrefied biomass in general and, as a result, stimulate development of global torrefied biomass markets. Results show that the torrefied biomass demand significantly depends on the bioenergy markets. It seems that despite of the challenges, the growth of torrefied biomass demand will have a large progress in coming years.
\end{abstract}

Keywords: Torrefaction, Biomass, Industrial application, Biomass market, Co-firing, Bioenergy. 


\section{List of Abbreviations and definitions}

CHP Combined heat and power

$\mathrm{CO}_{2} \quad$ Carbon dioxide

EU European Union

EU-28 Member States of the European Union since January 2013, when Croatia joined the EU

GHG Greenhouse Gas

LLC A limited liability company

IEA International Energy Agency

LHV Low Heating Volume

$\mathrm{NO}_{\mathrm{x}} \quad$ Nitrogen oxides

TOPs Torrefied pellets

UCLOS Ultra Low $\mathrm{CO}_{2}$ Steelmaking

USA United States of America

\section{Definitions}

- Bioenergy: Bioenergy refers to energy derived from biomass.

- Biomass: Refers to the biodegradable fraction of products, waste and residues from agricultural (including vegetal and animal substances), forestry and related industries, as well as the biodegradable fraction of industrial and municipal waste.

- Woody biomass: Refers to the trees and woody plants, including limbs, tops, needles, leaves, and other woody parts, grown in a forest, woodland, or rangeland environment, that are the by-products of forest management.

- Biofuels (=biomass fuel): Fuel produced directly or indirectly from biomass. The fuel may have undergone mechanical, chemical or biological processing or conversion or it may have had a previous use. Biofuel refers to solid, gaseous and liquid biomass-derived fuels.

- Torrefied biomass: Refers to biomass which is produced through torrefaction.

- Torrefied wood: Refers to woody biomass which is produced through torrefaction.

- Torrefied pellets: Refers to pellets which are produced out of torrefied biomass. 


\section{Introduction}

Biomass is a unique energy source in that it is globally available and renewable, unlike fuels such as oil and gas, which are concentrated in restricted geographical areas. It thus has the potential to play a significant role in the future energy mix in many countries. Due to the physical characteristics, raw biomass has difficulties competing with fossil fuels in many applications. However, pretreatment of solid biomass can improve its competitiveness. For example, pelletizing of biomass, which is applied commercially, gives higher energy density than raw biomass, although energy density still remains lower than that of coal [1]. Another promising technology for increasing the attractiveness of biomass can be torrefaction, which considerably improves the characteristics of biomass for energy utilization [2, 3-6].

Torrefaction is a mild thermal pretreatment process in which biomass is heated to $200-300^{\circ} \mathrm{C}$ in an oxygen-deficient atmosphere for an appropriate time (0.5-2 hours) [7]. Torrefaction process parameters are similar to those used in the roasting of coffee beans, and its effect on treated biomass can be described as a mild pyrolysis. With increasing final torrefaction temperature, the amount of volatiles being emitted during the process increases while hemicellulose, lignin, and cellulose are being decomposed [8]. The products of the torrefaction process are solid, liquid, and non-condensable gas. The main product of the torrefaction process is the solid, which is called torrefied biomass [9]. Figure 1 and 2 show the basic torrefaction principle and typical mass with energy balance (including sensible heat) for wood torrefaction respectively.

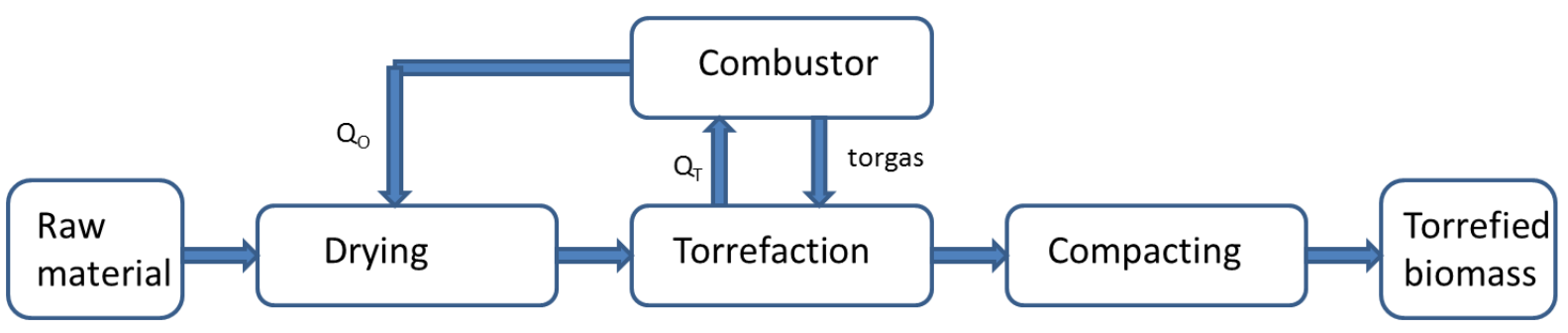

Figure 1: Basic torrefaction principle [10].

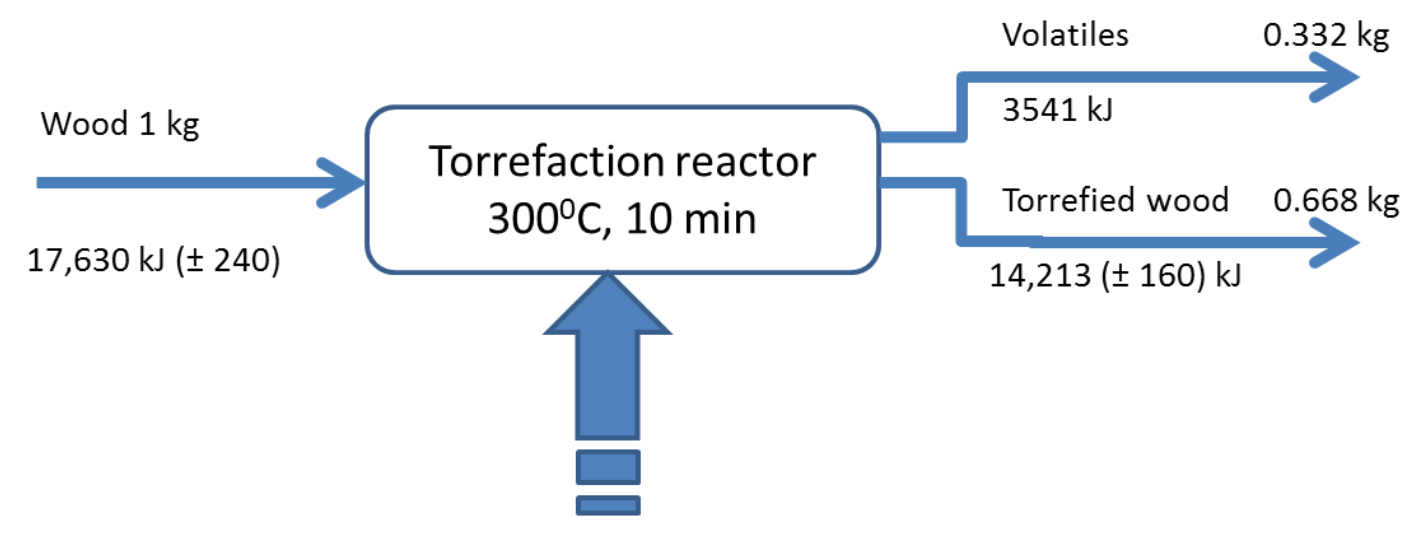

$124( \pm 400) \mathrm{kJ}$

Figure 2: Typical mass and energy balance (including sensible heat) for wood torrefaction [11]. 
Torrefied wood's energy content (caloric value) and energy density are similar to coal and greater than those of wood pellets (Table 1) [12]. Additionally, torrefied biomass presents lower ash content and is more environmentally-friendly than fossil fuel from the perspective of net greenhouse gas $(\mathrm{GHG})$ emissions $[3,13]$. These characteristics make torrefied biomass promising not only for final applications but also from a logistical point of view. For example, the high energy density of torrefied biomass decreases shipping costs and makes handling easier [8]. In comparison with biomass supply chain which has challenges [14], especially with regard to supply chain economics, torrefaction combined with pelletisation could be an attractive solution [8].

Table 1: Characteristics of some biomass types compared to coal, adopted from [13], * and ${ }^{* *}$ adopted from [3] and [15] respectively.

\begin{tabular}{|l|c|c|c|c|c|c|}
\hline & Unit & Wood chips & $\begin{array}{c}\text { Wood } \\
\text { pellets }\end{array}$ & $\begin{array}{c}\text { Torrefied } \\
\text { biomass }\end{array}$ & $\begin{array}{c}\text { Torrefied } \\
\text { biomass } \\
\text { pellets } \\
\text { (TOP) }\end{array}$ & $\begin{array}{c}\text { Bituminous } \\
\text { coal }\end{array}$ \\
\hline $\begin{array}{l}\text { Moisture } \\
\text { content }\end{array}$ & $(\%) \mathrm{wt}$ & $30,0-60,0$ & $7,0-10,0$ & 3,0 & $1,0-5,0$ & $5,0-10,0$ \\
\hline Mass density & $\left(\mathrm{kg} / \mathrm{m}^{3}\right)$ & $250-400$ & $600-650$ & 230 & $750-850$ & $800-1000$ \\
\hline LHV & $\mathrm{MJ} / \mathrm{kg}$ & $6,0-13,0$ & 16,2 & 19,9 & $19,0-22,0$ & $>25,0$ \\
\hline Ash $^{*}$ & $(\%) \mathrm{wt}$ & $0,7-10,0$ & $0,4-1,0$ & $<3,0$ & $<3,0$ & $10,0-40,0$ \\
\hline $\begin{array}{l}\text { Calorific } \\
\text { value }\end{array}$ & $\mathrm{MWh} / \mathrm{t}$ & $1,7-3,6$ & 4,5 & 5,5 & $5,2-6,2$ & 7,0 \\
\hline $\begin{array}{l}\text { Energy } \\
\text { density }\end{array}$ & $\mathrm{MWh} / \mathrm{m}^{3}$ & $0,7-0,9$ & 3,0 & 1,3 & $4,2-5,0$ & $5,6-7,0$ \\
\hline $\begin{array}{l}\text { Hygroscopic } \\
\text { nature* }\end{array}$ & Hydrophilic & Hydrophilic & $\begin{array}{c}\text { Moderately } \\
\text { hydrophobic }\end{array}$ & $\begin{array}{c}\text { Moderately } \\
\text { hydrophobic }\end{array}$ & Hydrophobic \\
\hline $\begin{array}{l}\text { Biological } \\
\text { degradation }\end{array}$ & & Fast & Fast & Slow & Slow & None \\
\hline $\begin{array}{l}\text { Product } \\
\text { consistency }\end{array}$ & & Limited & High & High & High & High \\
\hline
\end{tabular}

Describing the wood pellet market and trade Goh et al. [16] suggest that torrefaction can be attractive for pellet upgrading technology. An effective torrefaction system enables achievement of a consistent and homogeneous, fully hydrophobic, especially compared to normal wood pellets and stable product, allows utilization of diverse feedstock, and permits desired end-use energy densities [1]. Torrefied biomass can be prepared from different kinds of raw materials. All solid biomass can be a raw material for torrefaction [17]. Use of lower quality feedstock is also one of advantages of torrefaction [18]. The physical and chemical characteristics of torrefied biomass can be vary depending on the feedstock [19].

The high energy content per unit mass of torrefied biomass makes it very attractive for combustion and gasification applications. Furthermore, the technical performance of the torrefaction application offers promising prospects [20-25]. Several studies have shown that torrefaction can improve energy use, and reduce logistic costs from commercial scale operation of the process. Thus it has the potential to transform biofuel markets [13,26-28]. 
Thrän et al. [15] discusses that during the last years, the torrefaction technology has improved significantly and is now commercially available for woody biomass. Torrefied pellets (TOP) may become the dominant and preferred internationally traded solid biomass commodity in near future [17]. Deutmeyer et al. [27] suggest that the demand for TOPs could increase considerably and easily reach the 50 million dry ton per year threshold in the European Union (EU). Hawkins Wright Ltd., an independent British consultancy, suggests that global demand for torrefied biomass will exceed 70 million ton/year by 2020 [29].

Torrefied biomass could have potential in different industrial applications. However, there is limited knowledge of torrefied biomass use and potential in industrial applications. No studies have comprehensively investigated torrefied biomass use in non-power generation industrial applications, and no specific data are available about the current volume of torrefied biomass use in industrial and power applications.

The objective of this study is to evaluate the potential of torrefied biomass use in industrial applications based on a series of likely scenarios method. The study focuses on technical and market possibilities, and presents predictions of potential torrefied biomass demand in a number of industrial sectors. In addition, the study discusses the probable impact of these applications on the international trade in biomass markets. The aim of the study is to find out the accurate information about torrefied biomass applications. In addition to power sector, the reviewed nonpower generation industries are the iron and steel industry, the chemical and petrochemical industry, the paper, pulp and printing industry and non-metallic minerals (glass, ceramic, cement, etc.). This industries were chosen into the the study due to large energy consumption.

\section{Material and methods}

Firstly, this section shows the current biomass application. The integration of biomass into industries presents the general overview of how bioenergy attracts (or not attracts) attention of each industry. Secondly, torrefied biomass market is presented. It used as a basis of scenarios of possible torrefied demand developing. Finally, method of series likely scenarios is described.

\subsection{Biomass possibility in power and non-power generation sectors}

Biomass use in power stations is well developed. In large power plants, biomass in combination with coal is used to reduce GHG emissions, decrease fossil fuel use and promote sustainable energy development. Over 150 installations worldwide for most combinations of fuels and boiler types in the range 50-700 MWe have successfully demonstrated biomass co-firing [30]. Cofiring is very perspective method for a rapid introduction of biofuels into the existing system [31]. Table 2 shows the role of biomass in power generation in several geographical regions. 
Table 2: Use of biomass in power generation in several geographical regions in 2014 [32].

\begin{tabular}{|l|c|c|c|}
\hline \multirow{2}{*}{ Region } & \multicolumn{3}{|c|}{ Energy consumption (EJ) } \\
\cline { 2 - 4 } & Total & $\begin{array}{c}\text { By } \\
\text { power } \\
\text { station }\end{array}$ & $\begin{array}{c}\text { By } \\
\text { biofuel } \\
\text { and waste }\end{array}$ \\
\hline Asia & 182,1 & 75,0 & 0,02 \\
\hline Africa & 23,4 & 6,8 & 0,04 \\
\hline Canada & 8,4 & 4,0 & 0,06 \\
\hline $\begin{array}{l}\text { United } \\
\text { States }\end{array}$ & 64,4 & 37,7 & 1,0 \\
\hline Australia & 3,4 & 2,2 & 0,03 \\
\hline EU-28 & 46,3 & 29,0 & 2,2 \\
\hline Japan & 13,0 & 8,0 & 0,3 \\
\hline Brazil & 9,7 & 3,1 & 0,3 \\
\hline $\begin{array}{l}\text { Rest of } \\
\text { the world }\end{array}$ & 44,3 & 46,8 & 3,0 \\
\hline $\begin{array}{l}\text { Total } \\
\text { (world) }\end{array}$ & 395,0 & 215,3 & 6,9 \\
\hline
\end{tabular}

Biomass use for energy production is attractive not only in the power generation industry but also other industrial sectors. Distribution of biomass use by industries is uneven and biomass consumption profiles vary in different parts of the world depending on the status of industrial development, principal industrial sector and availability of biomass (Table 3) [32].

Table 3: Industrial biomass use as a part of total energy consumption in different regions in 2014 [32,33*].

\begin{tabular}{|c|c|c|c|}
\hline \multirow[t]{2}{*}{ Region } & \multicolumn{2}{|c|}{$\begin{array}{l}\text { Final energy } \\
\text { consumption (EJ) }\end{array}$} & \multirow[t]{2}{*}{$\begin{array}{l}\text { Studied non-power industrial sectors and its biomass and waste } \\
\text { consumption for energy (EJ) }\end{array}$} \\
\hline & Industry & $\begin{array}{l}\text { Biofuel } \\
\text { and waste }\end{array}$ & \\
\hline Asia & 56,7 & 2,4 & $\begin{array}{l}\text { Food and tobacco (total consumption 2,2 EJ) 0,3 EJ } \\
\text { Non-specified (industry) (total consumption } 9 \mathrm{EJ} \text { ) 2,1 EJ }\end{array}$ \\
\hline Africa & 3,6 & 0,8 & Non-specified (industry) (total consumption 2,3 EJ) 0,8 EJ \\
\hline Canada & 2,0 & 0,3 & $\begin{array}{l}\text { Iron and steel (total consumption } 0,2 \mathrm{EJ} \text { ) } 0 \mathrm{EJ} \\
\text { Chemical and petrochemical (total consumption } 0,3 \mathrm{EJ} \text { ) } 0 \text { EJ } \\
\text { Paper pulp and print (total consumption } 0,6 \mathrm{EJ} \text { ) } 0,3 \mathrm{EJ} \\
\text { Non-metallic minerals (total consumption } 0,1 \mathrm{EJ} \text { ) } 0,006 \mathrm{EJ}\end{array}$ \\
\hline $\begin{array}{l}\text { United } \\
\text { States }\end{array}$ & 11,2 & 1,3 & $\begin{array}{l}\text { Iron and steel (total consumption } 0,7 \mathrm{EJ} \text { ) } 0 \mathrm{EJ} \\
\text { Chemical and petrochemical (total consumption } 2,5 \mathrm{EJ} \text { ) } 0,01 \mathrm{EJ} \\
\text { Non-metallic minerals (total consumption } 0,7 \mathrm{EJ} \text { ) } 0 \mathrm{EJ} \\
\text { Paper pulp and print (total consumption 1,8 EJ) } 1,2 \mathrm{EJ}\end{array}$ \\
\hline Australia & 1,0 & 0,1 & $\begin{array}{l}\text { Iron and steel (total consumption } 0,04 \mathrm{EJ} \text { ) } 0 \mathrm{EJ} \\
\text { Chemical and petrochemical (total consumption } 0,1 \mathrm{EJ} \text { ) } 0,005 \mathrm{EJ} \\
\text { Non-metallic minerals (total consumption } 0,09 \mathrm{EJ} \text { ) } 0,001 \mathrm{EJ} \\
\text { Paper pulp and print (total consumption } 0,05 \mathrm{EJ} \text { ) } 0,02 \mathrm{EJ}\end{array}$ \\
\hline EU-28 & $11,5^{*}$ & 1,2 & $\begin{array}{l}\text { Iron and steel (total consumption } 1,2 \mathrm{EJ} \text { ) } 0,001 \mathrm{EJ} \\
\text { Chemical and petrochemical (total consumption } 2,0 \mathrm{EJ} \text { ) } 0,03 \mathrm{EJ} \\
\text { Non-metallic minerals (total consumption } 1,0 \mathrm{EJ} \text { ) } 0,2 \mathrm{EJ}\end{array}$ \\
\hline
\end{tabular}




\begin{tabular}{|l|c|c|l|}
\hline & & & Paper pulp and print (total consumption 1,2 EJ) 0,5 EJ \\
\hline Japan & 3,7 & 0,1 & $\begin{array}{l}\text { Iron and steel (total consumption 0,9 EJ) 0,002 EJ } \\
\text { Chemical and petrochemical (total consumption 0,8 EJ) 0,005 EJ } \\
\text { Non-metallic minerals (total consumption 0,5 EJ) 0,02 EJ } \\
\text { Paper pulp and print (total consumption 0,3 EJ) 0,1 EJ }\end{array}$ \\
\hline Brazil & 3,4 & 1,4 & $\begin{array}{l}\text { Iron and steel (total consumption 0,5 EJ) 0,1 EJ } \\
\text { Chemical and petrochemical (total consumption 0,3 EJ) 0,003 EJ } \\
\text { Non-metallic minerals (total consumption 0,4 EJ) 0,1 EJ } \\
\text { Paper pulp and print (total consumption 0,5 EJ) 0,3 EJ }\end{array}$ \\
\hline $\begin{array}{l}\text { Rest of the } \\
\text { world }\end{array}$ & 22 & 0,5 & 8,1 \\
\hline $\begin{array}{l}\text { Total } \\
\text { world) }\end{array}$ & 115,1 & $\begin{array}{l}\text { Iron and steel (total consumption 21,5 EJ) 0,1 EJ } \\
\text { Chemical and petrochemical (total consumption 17,9 EJ) 0,07 EJ } \\
\text { Paper pulp and print (total consumption 6,4 EJ) 2,6 EJ } \\
\text { Non-metallic minerals (total consumption 16,9 EJ) 0,4 EJ }\end{array}$ \\
\hline
\end{tabular}

Koppejan et al. [34] suggest that the share of torrefied biomass use in industrial applications in the EU could be 5\%-10\% of all biomass use in the near term. Most European countries have a strong possibility of torrefied biomass use in non-generation industries. In Nordic countries, mainly in Sweden and Finland, the pulp and paper sector has set a target to reduce $\mathrm{CO}_{2}$ emissions and biomass pre-treatment technology seems very attractive [35,36].

\subsection{Torrefied biomass market}

The location of large volume production capacity of torrefied biomass will have a significant effect on the development of bioenergy markets [27]. Countries that have ambitious targets for increased biomass use and strong industrial production could be the main buyers of torrefied biomass. Targets of increasing bioenergy in the EU-28 [37] stimulate further development and implementation of torrefied technology [15]. In Europe, the total biomass residue available for torrefaction is about 4,2 EJ [38]. Biomass torrefaction facilities are currently found in a number of EU countries, such as the Netherlands, Sweden, France and Spain [7,29,39], and several demonstration plants have started up in the last two years. The launching of torrefied biomass production, albeit currently on a relatively small scale (Figure 3), brings opportunities for torrefied biomass trade within Europe and elsewhere. 


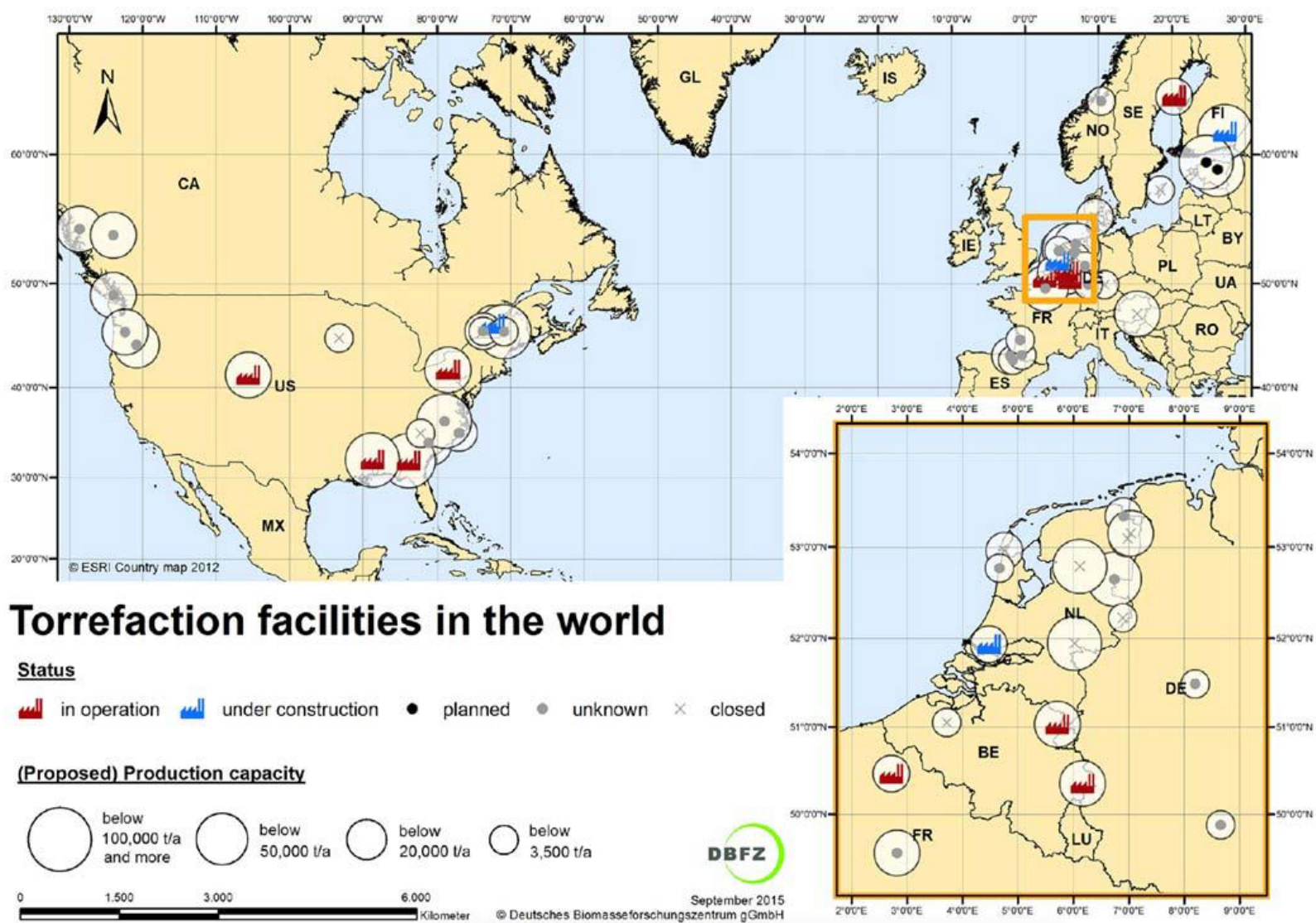

Figure 3. Worldwide activities of biomass torrefaction facilities with different development status (the status "unknown" describes initiatives which have been active in the last years but whose current status could not be verified; the lacking information policy indicates difficulties in operation, their dominance shows the recession in current torrefaction developments) [15].

A number of countries, such as Canada and USA, have relatively strong positions in torrefied biomass production and development and could become the main suppliers in future torrefaction products markets. Torrefied-biomass production could significantly increase biomass trade in the US market. New Biomass Energy LLC is launching a joint venture with Solvay for expansion of torrefied-biomass production [40]. The company's plant in Quitman, Mississippi, is the largest torrefaction facility in North America. This project planned to establish an annual production capacity of $10 \mathrm{PJ}$ by the end of 2014. Solvay Biomass Energy will promote its torrefied pellets for electricity production in Europe and Asia. The joint-venture company is capable of producing TOPs at a commercial level [40]. There is a large-scale torrefaction demonstration application also in Canada. In addition, for instance, Airex Energy and Diacarbon will have a combined production capacity of 1,7 PJ per year of TOPs in 2015 [41,42]. Production for export could be possible as a consequence of the large forestry sector and excellent opportunities for export of torrefied biomass [8]. Additionally, Brazil, South Africa and several Asian countries such as Malaysia, Indonesia, Japan, and South Korea have interest in torrefied biomass [43].

Due to benefits of storage and handling properties, torrefied biomass gives strong opportunities for the expanded use of bioenergy in Europe. On the European market, torrefaction can offer increased cost competitiveness, the possibility of using established technology, the development of commodity status, and a broadening of feedstock possibilities [35]. Ranta et al. [44] have mentioned that the cost range of TOPs was 32.9-46.2 $€ / \mathrm{MWh}$ according to the raw material costs 
which were the most crucial cost parameter in the sensitivity analysis, and that is the situation in Finland. Currently, all torrefied biomass producers, wherever located throughout the world, are oriented to European demand [27]. Consequently, there is considerable potential for the creation of a dynamic torrefied biomass market in Europe, of which demand for industrial production would be a part.

\subsection{Scenarios}

Based on information on current biomass use and technical possibilities of torrefied biomass use in industry, this study roughly estimates torrefied biomass prospects for all the industrial sectors studied based on a series of likely scenarios. Detailed discussion of past and existing torrefied biomass use in industries is excluded from the analysis as it was not within the scope of this study. Although the forecasting method used only gives an approximate assessment, the results provide some indication of possible future torrefied biomass demand from industry. Furthermore, the timescale considered is relatively short and dramatic changes in consumption patterns are checked by the large investments required.

The scenario analysis is very developed method and used in different studies regarding prediction of biomass for energy production. Lamers et al. [45], for example, using supply and demand scenarios discuss the global solid biomass trade for energy by 2020 . Hoefnagels et al. [46] shows scenarios projections for internal and domestic uses of solid biomass in the EU.

In this study, for finding the answer for the research question three scenarios were developed as follows. Scenario one is an optimistic, which focuses on the technical and economic advantages of torrefied biomass use. The optimistic scenario considers the case of large, mass torrefied biomass production and strong market developed which can exist in coming years. Scenario two is a pessimistic, which focuses on the situation where the torrefied biomass has stagnation or very weak development. It can be happed due to stagnation of total bioenergy markets and/or other factors such as weak interest of large industries in torrefied biomass due to low cost of fossil fuels etc. Scenario three is a most likely scenario, which combine something average between previous both. If the market development of torrefied biomass will be develop, but not so fast as in Scenario one. Figure 4 shows the method of a series of likely scenarios

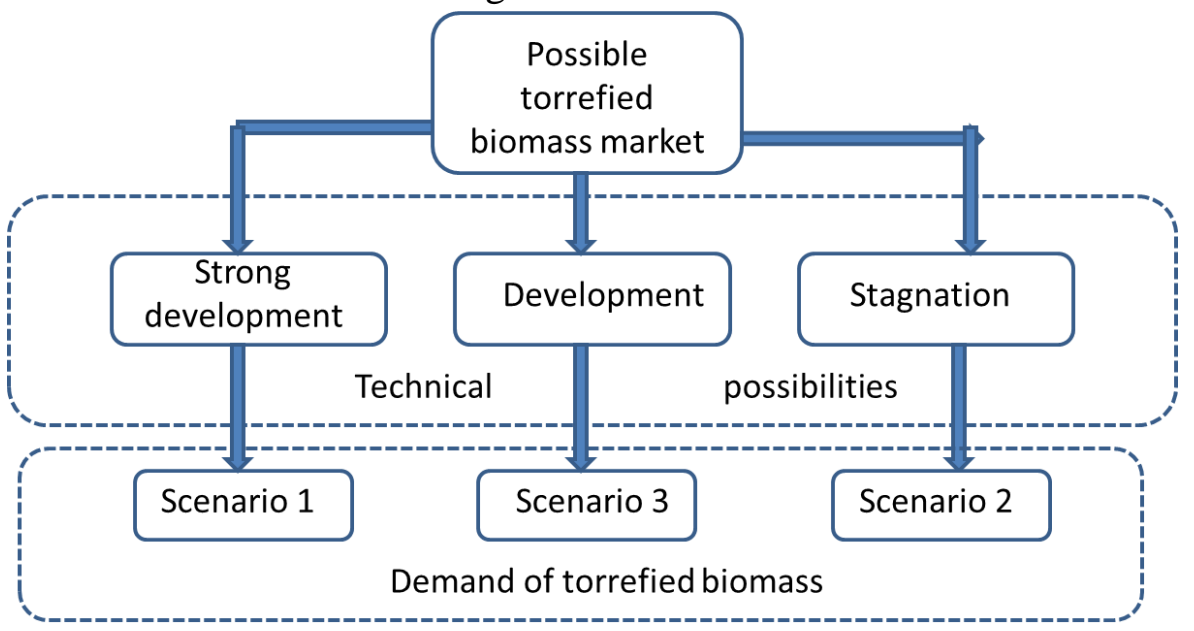

Figure 4: Scenarios of projected torrefied biomass demand. 
In particular, the analysis of torrefied biomass demand is problematic. Firstly, there are not available data about current use of torrefied biomass in industrial applications. Additionally, currently there is no information available about the torrefied biomass demands by industries. Secondly, current well developed biomass consumption in industries can not guarantee the similar development of torrefied biomass in the future (for example, in pulp and paper industry) because characteristics of biomass and torrefied biomass are different. Finally, torrefied biomass is a relatively new product on the energy markets.

Additionally, the limitations of this study relate to the following aspects in particular that the forecast in this study does not include possible changes on the global energy market, such as dramatic changes in fossil fuel prices and changes in economic conditions, which can influence biomass and energy use as a whole. The period of study 2010-2015 was chosen as the main starting point and information was updated based on data availability. This study does not include the historical development of biomass use in industry.

The presented findings need to be interpreted in the light of the above limitations and further investigation to verify the results of this work is clearly desirable. The analysis of the technical potential of torrefied biomass use in this study is able to support other possible scenarios for estimation of future torrefied biomass as well as forming a basis for assessment of possible new torrefaction applications.

The information used reflects the status at the end of the year 2015. The study was done using literature, databases, reports and reviews, most of them publicly available. It was complemented with information from personal communications with IEA Bioenergy Task 40 members within the "Possible new industrial users of torrefied biomass" study program [8].

\section{Results}

The industrial sector consumes about $37 \%$ of the world's total delivered energy, with natural gas and coal being the primary fuel in industrial usage [47]. However, such fossil-based fuels are not as environmentally-friendly as fuels produced from renewable resources, and along with other drivers like public policy incentives and energy security considerations, interest in renewable fuels is increasing across many industrial sectors. Torrefaction can be a solution for increasing bioenergy development. The section analyses the technical possibility of torrefied biomass use in studied industry and projected future torrefied biomass demand based on three scenarios.

\subsection{Technical possibilities of torrefied biomass consumption in the power generation sector} Torrefied biomass has potential use in coal power plant combustion units. Large scale coal power plants are one of the main drivers of technological development of biomass upgrading through torrefaction [34,48]. Prospects for future development of torrefied biomass use in such facilities seem attractive. Several studies present the technical benefits of torrefied biomass use in the power sector. Tsalidis et al. [49], for example, demonstrate the benefits of torrefied biomass use in coal-fired power generation plants in the Netherlands. In 2012, Li et al. [50] using process simulation software (Aspen Plus) and analyzing the possibility of co-firing torrefied biomass in a 220 MWe coal-fired power plant concluded that $100 \%$ torrefied biomass usage with maximum efficiency and minimum emissions is technically possible. Huang et al. [51] and Basu 
et al. [52] demonstrate environmental benefits using torrefaction in power plant in Taiwan and in the eastern Canada respectively. Liu et al. [53] suggest benefits of co-firing torrefied bamboo with coal and suggest that combustion characteristics of torrefied bamboo closer to coal.

In 2012, co-gasification test with 1,200 tons of TOPs was tested in Buggenum power plant in the Netherlands. In 2013, about 2,300 tons of TOPs were successfully co-fired at a 5\% - 25\% cofiring rate at the Amer 9 power plant also in the Netherlands. Tests show that torrefied biomass can replace coal using the existing coal infrastructure in large scale power generation [18]. According to American company Konza Renewable Fuels LLC, the introduction of torrefied biomass in all phases of production that involve coal or derivative products of coal is beneficial [54]. Rousset et al. [24] show that a pulverized coal boiler could be fired $100 \%$ by torrefied biomass without an obvious decrease of boiler efficiency nor fluctuation of the boiler load and significant changes in boiler capacity. Additionally, torrefied biomass use in industry could significantly decrease emissions related with $\mathrm{CO}_{2}$ and $\mathrm{NO}_{x}[34,55]$. In laboratory scale, regimes of $100 \%$ firing of torrefied biomass are possible with minimum adjustments to the coal power plant's combustion units and at significantly reduced derating compared to wood pellets [17]. Currently, the volumes of torrefied biomass in power sector have been negligible and most applications have worked as test regime. The integration of torrefied biomass to large combined heat and power (CHP) plant requires a large amount of torrefied biomass, which does not exist on the market nowadays [44]. However, in the light of the mentioned studies in this section it seems that increased use of torrefied biomass could be attractive in the power generation sector in long-term perspective.

\subsection{Technical possibilities of torrefied biomass consumption in non-power generation industries}

The section analyses the possibility of torrefied biomass use in a number of non-power generation industries such as the iron and steel, the pulp and paper, non-metallic minerals as well as chemical and petrochemical industries.

\subsubsection{Iron and steel industry}

The iron and steel industry is the largest industrial source of $\mathrm{CO}_{2}$ emissions (over about $28 \mathrm{EJ}$ in 2010). The industry has the energy intensity of steel production and very large fossil fuel consumption [56]. The volume of energy use in this industrial sector offers clear potential for biofuel use and biofuel development, and biomass use in the steel industry has been recognized as a promising area for development. For example, the EU and Australia have introduced a forest-based biomass program for steel production [57]. Ultra Low $\mathrm{CO}_{2}$ Steelmaking (UCLOS) is a consortium of 48 partners, of which eight core members serve as leaders representing the European steel industry [58]. The project aims to enable a radical reduction in $\mathrm{CO}_{2}$ emissions from steel production. Improvements to charcoal production processes and development of a sustainable and effective biomass supply form a major part of the initiative $[57,58]$.

The steel sector requires high-quality fuels for its industrial processes, and many common biomass fuels fail to meet the required criteria for energy density, ash production and ease of handling. One possible biomass fuel solution could be to replace coking coal with torrefied wood [19]. Several studies [54,59-64] show that up to full replacement of pulverized coal 
injection with torrefied biomass injection (150-200 kg/t hot metal) is possible in iron and steel production. Furthermore, 100\% of torrefied biomass can be used pulverized coal boilers without remarkable decrease in boiler efficiency and fluctuations in boiler load [24]. Use of torrefied biomass to replace fossil fuels would significantly decrease $\mathrm{CO}_{2}$ emissions versus fossil fuels. Wang et al. [65], for example, suggest that in Sweden pulverized coal can be easily replaced by torrefied biomass in the steel industry, which is currently the big consumer of coal in the country.

Gasification research examining Brazilian biomass and its applications in the iron and steel industry is being undertaken by a Finnish-Brazilian research group. In the first phase of the project, gasification tests of potential biomass sources are being performed and material balances evaluated for an iron-pellet indurating furnace [62]. The possibility of torrefied biomass use was investigated in Ruukki Oy's steel plant in Raahe, Finland, which has approximately 92 PJ of steel production per year. Results show that full replacement of pulverised-coal injection with charcoal injection (150-200 kg/t hot metal) would be possible. For such production, maximum annual need is evaluated as $17 \mathrm{PJ}$ of charcoal and around 2,7 million $\mathrm{m}^{3}$ of green wood (e.g. forest chips) [66].

\subsubsection{Pulp and paper industry}

Biomass usage for energy production plays an important role in the pulp and paper industry. Ljungstedt et al. [67] show that increased demand for biomass in the pulp and paper industry has led to greater competition for raw material but also opened new opportunities for increased refining of intermediate products and by-products.

Torrefaction has attracted the attention of major pulp and paper producers. For example, Andritz, an Austrian engineering company, has two torrefied biomass production installation for their own facilities in Frohnleiten, Austria and Sønder Stenderup, Denmark [68]. Japanese paper manufacturing company, Nippon Paper, which is one of the world's biggest pulp and paper companies, has tested the use of torrefied pellets in order to turn towards power production sector due to loose demand in paper [69]. In April 2013, the company conducted experiments on co-firing of a pulverized coal boiler at the Yatsushiro Mill in Japan. It was found that a 25\% load (as weight ratio) of TOPs could be incorporated into the maximum fuel load of the boiler [70]. The experiments further confirmed that use of torrefied fuel does not cause problems with the runnability of a coal pulverizing facility and combustibility of fuel [70].

In the future, the pulp and paper industry may import regionally produced biomass instead of purchasing fossil energy and could extend the industry's mission from simply manufacturing low-margin products into new products such as 'green' power and torrefied biomass. This could improve the efficiency and profitability of their traditional core business. The use of biomass, primarily for process heat, could increase in the pulp and paper industry significantly [71]. The main European leaders in this industry are three Nordic companies, SCA, Stora Enso and UPM. These companies maintain contact with various research centers and organizations and are interested in new trends in bioenergy, including torrefaction [8]. 


\subsubsection{Non-metallic minerals (glass, ceramic, cement)}

The cement sector is the third-largest energy consumer in industry and the second-largest $\mathrm{CO}_{2}$ emitter (2 $094 \mathrm{MtCO}_{2}$ in 2010) [72]. The most likely applications in which torrefied biomass can be used are co-firing with coal in pulverised coal fired power plants and cement kilns, dedicated combustion in small-scale pellet burners, and gasification in entrained flow gasifiers that normally operate on pulverized coal [73].

The Canadian company, "Airex, Energy" has reported excellent test results for torrefied biomass in a ceramic plant [52]. Approximately 10 tons of torrefied biomass were used in co-firing tests at Colacem's cement plant in Grenville-sur-la-Rouge, Quebec, where torrefied biomass was cofired with conventional coal [51,52]. Another Canadian company, Diacarbon Energy Inc. will produce 25000 tons of torrefied biomass per year, starting in 2015, for replacement of coal in Lafarge Canada's cement plant in British Columbia [53].

\subsubsection{Chemical and petrochemical industry}

Although the petrochemical industry is a mature industry, the landscape continues to change. Historically important production areas (the USA, Europe, and Japan) have seen their share of the market contract decreasing in favour of Asia and the Middle East. Petrochemical-industry actors are increasingly considering basing their production processes on biomass, a renewable and abundant resource [74]. In many countries, especially in Scandinavia, bioenergy use is already quite well established in the chemical and mechanical forest industries, which are able to use their own by-products in their energy production [19].

Currently, biomass use in the chemical and petrochemical industry is under intensive research and development. Johansson et al. [75] demonstrate the great advantages to be gained in global $\mathrm{CO}_{2}$ emission reduction through coal replacement by biomass. However, Vennestrøm et al. [76] found that biomass use in the petrochemical industry is not optimal in the long term due to the insufficient amount of biomass available to meet the demand for fuel and differences in the chemical characteristics of used fuels and biomass. However, the authors see possibilities for biomass development in the chemical industry if challenges such as the need for large investments can be addressed. Available biomass should suffice to replace the share of fossil feedstock used in chemical production. The chemical characteristics of biomass and many bulk chemicals are very similar. In chemical industry gasification require a huge amount of biomass which requires large space for storage. Torrefied biomass can be a good solution in such a case.

\subsection{Projected future torrefied biomass demand (3 Scenarios)}

Future torrefied biomass demand will depends on the many factors such as market conditions, technical possibilities and common trend of bioenergy development. The section shows three possible scenarios of torrefied biomass demand development.

\subsubsection{Optimistic Scenario (Scenario 1)}

Logistics and transport is a key cost components in the biomass value chain [17]. Thus due to logistic benefits (see Sections 1 and 4) torrefied biomass has a very promising perspective on the global biomass markets. Last few years showed that the use of torrefaction technology is changing rapidly as new producers join to the market and demand increases. Mobini et al. [28] present a model that is applied to an existing wood-pellet supply chain in British Columbia and 
analyse the difference in price between torrefied pellets and wood pellets. The case study shows that integration of torrefaction into the wood pellet production and distribution supply chain leads to lower delivery cost to existing and potential markets, due to the increased energy density and lower distribution costs. The delivered cost of torrefied pellets (€/GJ) in North-West Europe is $9 \%$ lower than that of regular pellets [28]. Thanks to the more efficient transport, the energy consumption and the $\mathrm{CO}_{2}$ emitted along the supply chain are decreased for torrefied pellets. Integration of torrefaction into the wood-pellet production and distribution supply chain could result in less expensive and cleaner biofuel [28]. Torrefied biomass may offer additional benefits to leverage infrastructure beyond that of pelleting biomass [17].

In the light of such benefits, if the market of torrefied biomass will significantly developed, the torrefied wood pellets can compete with wood pellets and show slightly similar trade streams. Figure 5 shows the projected streams of torrefied biomass.

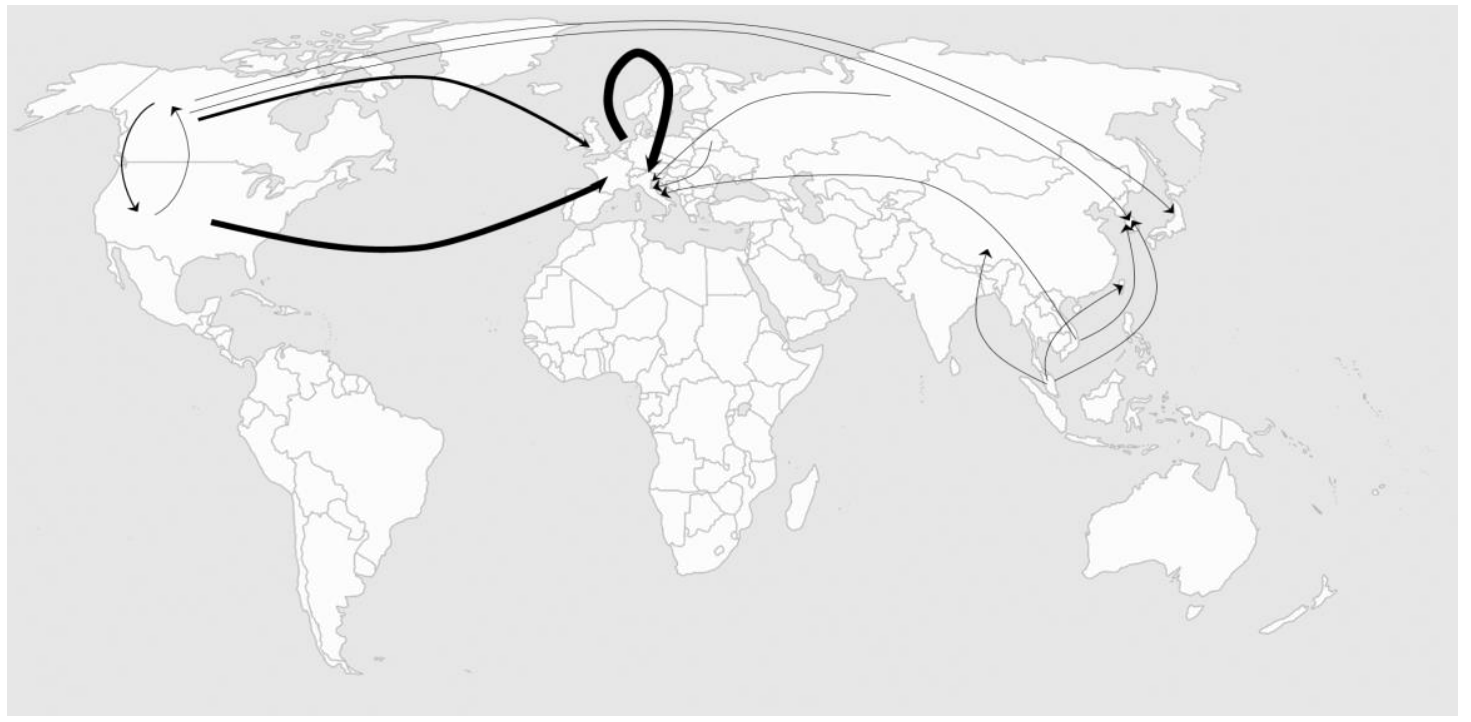

Figure 5: The projected streams of torrefied biomass.

As for the geographical breakdown of industrial demand for torrefied biomass, Canada and the USA, as key producers of torrefied biomass, could be more export-oriented, especially as high domestic demand in industry is not predicted for these countries. The greatest share of torrefied biomass consumption in industrial consumption will be seen in industrial sectors in European countries. Existing and new plants for torrefied-biomass production in various parts of the world could stimulate demand for torrefied biomass in industry. In the near future, given development and stable work in torrefied-biomass production, an increase in torrefied biomass demand from the industrial sector in Europe is possible. This would, in turn, stimulate intensive development of the biomass and biofuel trade.

According to optimistic scenario (Scenario 1) of the study torrefied biomass demand can reach roughly $15-18$ million tons (630-755 PJ) by 2030. Might be optimistic scenarios seem very ambitios. However, if to glance the large progress of wood pellet trade during the last 5-10 years $[16,17,77,78]$ the torrefied pellets can show the same progress due to attractiveness of torrefied biomass use in power industry and non-power such as iron and steel and non-metallic minerals industries as well as logistic. 


\subsubsection{Pessimistic scenario (Scenario 2)}

Current production of torrefied biomass is under development. Biggest plant in Mississippi with capacity of 0.8 million tons per year of TOPs produced 8000 tons of torrefied pellets in 2015 . Torrefied pellets were used only for tests [79]. To our knowledge there is no large scale existent with torrefied pellets in industry. There are experiments in industry which is done mostly in test regime.

Although the significant technical progress of torrefaction was done, torrefaction technology commercial market introduction appears slower and more difficult than initially anticipated. It can be explained by the fact that European utilities are no longer very eager to invest in torrefaction plants or exhibit weak interest in long-term agreements for torrefied materials. Many European countries have the current lack of incentives for co-firing [43].

In the pessimistic scenario (Scenario 2) of the study torrefied biomass demand can reach roughly 2-5 million tons (84-210 PJ) by 2030. Industries are interested in decrease of emissions and dependence from fossil fuels as well as show general trend of biomass increase development allows suggesting that torrefied biomass will develop, might be not very fast as in the optimistic scenario. In the pessimistic scenario the major consumer of torrefied biomass will be the power industry and non-power sector will be significantly lag behind. There is very limited knowledge about all aspects of torrefied biomass use in non-power industries. Despite the beneficial characteristics of torrefied biomass as a fuel, its integration into non-power generation industry operations is very slow and still in its early stages. For example, in a number of industries, such as chemical and petrochemical industries, the share of biomass use in total energy consumption is not very large (Table 3) and integration of new biofuels such as torrefied biomass is rather slow (section 3.2.4). Due to weak development of biomass use in the chemical and petrochemical industry, large torrefied biomass usage is unlikely.

\subsubsection{Most likely scenario (Scenario 3)}

Generally, all two scenarios estimate that torrefaction use will increase and the increase will depend on many factors such as market conditions, technical and economical possibilities. Figure 6 provide roughly indication of possible torrefied biomass demand by the studied industries.

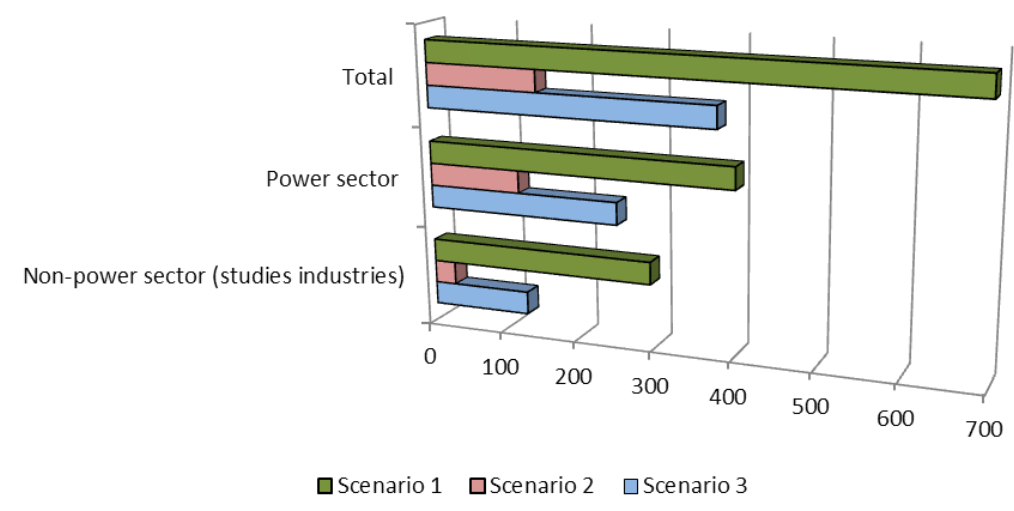

Figure 6: Roughly projected torrefied biomass demand by industries in 2030 (in PJ). 
In the "likely scenario" (Scenario 3) of the study torrefied biomass demand can reach roughly 810 million tons (335-420 PJ) by 2030. The feasibility, from a technical standpoint, of more extensive use of biomass in non-metallic minerals and iron and steel industries has been demonstrated, and use of torrefied biomass in the biomass usage mix would seem attractive. The pulp and paper industry currently uses a large amount of biomass and technical possibilities for the use of torrefied biomass seem also very attractive. In these industries the complete replacement of fossil fuel by torrefied biomass technically would seem possible. Consequently, it can be expected that in addition to greater overall use of biomass, torrefied biomass use will also increase significantly in these industries. Nevertheless, it would appear that, overall, the power generation sector can be the main consumer of torrefied biomass and its consumption will far exceed that of other industrial sectors.

\section{Discussion}

The future of torrefied biomass markets will depends on the price. At the moment, there is no market in place for torrefied pellets in practice; therefore, no specific information is available on market prices. The capital costs for a torrefied pellet plant are higher than those of a conventional wood pellet plant. Several studies have shown that the high price of torrefied biomass can be compensated by several benefits. Bradley et al. [48] demonstrates the benefits of shipping torrefied pellets with coal. If we supply $10 \%$ TOPs with $90 \%$ coal by ship, the result could be 2-3 times less expensive per shipment than a supply chain for $100 \%$ wood pellets.

Describing the biomass torrefaction supply chain costs, Svanberg et al. [80] suggest that amount of available biomass, biomass premium, logistics equipment, biomass moisture content, drying technology and torrefaction mass yield as well as torrefaction plant capital expenditures are the most important parameters affecting total cost.

Presenting an economic comparison of torrefaction and conventional pellet production based on an end-use point of view, Ehrig [81] concluded that the production costs from the pretreatment phase are much higher for torrefied pellets, but these are partly compensated by reduced transport and logistics costs. At the end user, the torrefied fuel delivered is still more expensive than conventional pellets. Conversion TOPs to heat for domestic use is still more expensive than use of premium wood pellets. In contrast, the conversion of industrial torrefied pellets is at the same cost level as that of industrial wood pellets. Thus torrefaction offers certain opportunities to replace or complement conventional wood-pellet production and supply. Suppliers can use the same logistics and transport as for wood pellets [64], supply costs are reduced slightly (9\%) on account of the higher bulk density (relevant for transport by train and ship), and supply costs can be decreased by approximately $10 \%$ by taking advantage of the higher energy density. Suopajärvi et al. [66] show that the energy return on investment of torrefied wood in the steel industry seems attractive. Additionally Agar et al. [82] suggested that 4.5 GJ of energy is consumed for each tons of TOPs.

Comparison of torrefied and regular wood pellets in terms of cost at delivery and energy production shows that torrefied pellets are competitive with conventional pellets. These results further support the idea of torrefied biomass advantages. Therefore, it seems that although a huge increase in torrefied biomass consumption by non-power generation industry is not foreseeable 
compared with power sector, industrial use by actors outside the energy generation sector could increase demand for torrefied biomass in general and, as a result, stimulate development of global torrefied biomass markets. Non-power generation industries can be seen as the bridge towards the large markets e.g. power sector. New end-use purposes for torrefied biomass will help to scale-up the markets. Due to significant reductions in transportation costs in longdistance transportation and because of its physical characteristics, torrefied biomass could become a globally traded bioenergy carrier comparable with coal.

\section{Conclusion}

The study is the first attempt to evaluate the torrefied biomass application. The results of the study show that the evaluation of future torrefied biomass demand is very complicated. There are not available data about current use of torrefied biomass in industrial applications and limited knowledge of its implementation in industries such as chemical and petrochemical industry, pulp and paper etc. Also, the market of torrefied biomass is relatively on the earlier stage and its future seems unclear.

Although scenarios presented in a study have general estimation, the study has shown that torrefied biomass demand will increase due to the development of the new torrefied biomass production facilities, interest of emissions and fossil fuel use decrease by industries. Torrefaction has attractive technical possibilities in the power generation sector (mostly large CHP) which can be the leader in torrefied biomass use, and other areas such as the steel and iron as well as nonmetallic minerals industries.

Although little practical experience exists of the whole production and transportation chain of long-haul torrefied biomass trade and conversion at this early development stage, all findings of this study indicate that torrefied and compacted energy biomass has the potential to replace regular wood pellets as the most important internationally traded source of energy biomass for industrial use, such as co-firing or gasification in the long-term perspective. In order to make this happen, considerable investments are needed to establish integrated supply chains from sustainable feedstock sources (e.g. supported by European utilities in order to secure long-term feedstock supplies for co-firing in coal power plants) and initiate the process of commoditization of torrefied biomass.

The present study makes several noteworthy contributions to torrefaction technology. This study was a first attempt to estimate the potential for torrefied biomass in industrial applications. Further investigations are needed to provide detailed estimations focusing on the main opportunities and restrictions as well as the economics of torrefied biomass use in industrial applications in more detail. In addition, study investigating other possible consumers of torrefied biomass not considered in this work and dipper analysis of emission reduction would be of value.

\section{Acknowledgements}

The research was done in conjunction with the IEA Bioenergy Task 40 (http://www.bioenergytrade.org/) research project, "Possible new industrial users of torrefied biomass", financed partly by IEA Bioenergy Task 40. In addition, we would like to thank Peter Jones and Jarno Föhr from Lappeenranta University of Technology for valuable comments. 


\section{References}

[1] B. Batidzirai, F. van der Hilst, H. Meerman, MH. Junginger, APC. Faaij, Optimization potential of biomass supply chains with torrefaction technology, Biofuel Bioprod Bioref 8(2) (2013) 253-282.

[2] MJC. van der Stelt, H. Gerhauser, JHA. Kiel, KJ. Ptasinski, Biomass upgrading by torrefaction for the production of biofuels: A review, Biomass and bioenergy 35 (2011) 3748-3762.

[3] B. Batidzirai, APR. Mignot, WB. Schakel, HM. Junginger, APC. Faaij, Biomass torrefaction technology: Techno-economic status and future prospects, Energy 62 (2013) 196-14.

[4] W-H. Chen, J. Peng, XT. Bi, A state-of-the-art review of biomass torrefaction, densification and applications, Renew Sust Energ Rev 44 (2015) 847-866.

[5] WH. Chena, WY. Chenga, KM. Lub, YP. Huangc, An evaluation on improvement of pulverized biomass property for solid fuel through torrefaction, Applied Energy 88(11) (2011) 3636-3644.

[6] M. Wilk, A. Magdziarz, I. Kalemba, P. Gara, Carbonisation of wood residue into charcoal during low temperature process, Renewable Energy 85 (2016) 507-513.

[7] E. Dahlquist, Technologies for Converting Biomass to Useful Energy. New York, CRC Press; 2013, pp. 218-220.

[8] IEA Task 40. Possible effects of torrefaction on biomass trade. 2015.

[9] N. Soponpongpipat, U. Sae-Ueng, The effect of biomass bulk arrangements on the decomposition pathways in the torrefaction process, Renewable Energy 81 (2015) 679-684.

[10] International biomass torrefaction council. Torrefaction. http://www.biomasstorrefaction.org/torrefaction/ 2014 (accessed 28.09.16).

[11] M.J. Prins, K.J. Ptasinski, F.J.J.G. Janssen. More efficient biomass gasification via torrefaction, Energy 31(15) (2006) 3458-3470.

[12] A. Pirraglia, R. Gonzalez, D. Saloni, J. Denig, Technical and economic assessment for the production of torrefied ligno-cellulosic biomass pellets in the US, Energy Conversion and Management 66 (2013) 153-164.

[13] LJR. Nunes, JCO. Matias, JPS. Catalão, A review on torrefied biomass pellets as a sustainable alternative to coal in power generation, Renewable and Sustainable Energy Reviews 40 (2014) 153-160.

[14] B.H. Ba, C. Prins, C. Prodhon, Models for optimization and performance evaluation of biomass supply chains: An Operations Research perspective, Renewable Energy 87(2) (2016) 977-989.

[15] D. Thrän, J. Witt, K. Schaubach, J. Kiel, M. Carbo, J. Maier et al, Moving torrefaction towards market introduction-Technical improvements and economic-environmental assessment along the overall torrefaction supply chain through the SECTOR project, Biomass and Bioenergy 89 (2016) 184-200.

[16] C.S. Goh, M. Junginger, M. Cocchi, D. Marchal, D. Thrän, C. Hennig et al, Wood pellet market and trade: a global perspective, Biofuel Bioprod Bioref 7 (1) (2013) 24-42.

[17] P. Lamers, E. Searcy, J.H. Hess, H. Stichnothe, Developing the global bioeconomy, technical, market, and environmental lessons from bioenergy, Elsevier Inc. 2016. 
[18] BlackWood technology, Overview co-firing tests 2012-2015, IBTC Torrefaction Workshop Maarten Herrebrugh (CEO Blackwood Technology), Rotterdam, 2016.

[19] E. Alakangas, M. Junginger, J. van Dam, J. Hinge, J. Keränen, O. Olsson, et al, EUBIONET III-Solutions to biomass trade and market barriers, Renew Sust Energ Rev 16(6) (2012) 4277-4290.

[20] PCA. Bergman, JHA. Kiel, Torrefaction for biomass upgrading, In: the 14 European Biomass Conference \& Exhibition, Paris, France, 2005.

[21] S-W. Park, C-P. Jang, K-R. Baek, J-K. Yang, Torrefaction and low-temperature carbonization of wood biomass: Evaluation of fuel characteristics of the products, Energy 45(1) (2012) 676-685.

[22] MR. Kabir, A. Kumar, Comparison of the energy and environmental performances of nine biomass/coal co-firing pathways, Bioresource Technology 124 (2012) 394-405.

[23] P. Basu, Biomass Gasification, Pyrolysis and Torrefaction (Second Edition), UK: Elsevier Inc; 2013, pp. 87-145.

[24] P. Rousset, K. Fernandes, A. Vale, L. Macedo, A. Benoist, Change in particle size distribution of Torrefied biomass during cold fluidization. Energy 51(1) (2013) 71-77.

[25] L. Rosendahl, Biomass combustion science, technology and engineering, UK: Woodhead Publishing Limited, 2013, pp. 36-57.

[26] A. Uslu, APC. Faaija, PCA. Bergman, Pretreatment technologies, and their effect on international bioenergy supply chain logistics. Techno-economic evaluation of torrefaction, fast pyrolysis and pelletisation, Energy 33 (2008) 1206-1223.

[27] M. Deutmeyer, D. Bradley, B. Hektor, JR. Hes, L. Nikolaisen, JS. Tumuluru, et al, Possible effect of torrefaction on biomass trade, IEA Bioenergy Task 40; 2012.

[28] M. Mobini, JC. Meyer, F. Trippe, T. Sowlati, M. Fröhling, F. Schultmann, Assessing the integration of torrefaction into wood pellet production, Journal of Cleaner Production 78 (2014) 216-225.

[29] Hawkins Wright Ltd. The supply chain economics of biomass torrefaction; http://www.hawkinswright.com/Bioenergy-Multi_client_reports, 2012 (accessed 8.05.14).

[30] F. Al-Mansour, Z. Zuwala, An evaluation of biomass co-firing in Europe, Biomass and Bioenergy 34(5) (2010) 620-629.

[31] B. Hillring, Incentives for co-firing in bio-fuelled industrial steam, heat and power production-Swedish experiences, Renewable Energy 28(5) (2003) 843-848.

[32] World energy balance. IEA, http://www.iea.org/Sankey/index.html; 2016 (accessed 8.10.16).

[33] Eurostat data. Final energy consumption by industry, http://ec.europa.eu/eurostat/tgm/table.do?tab=table\&init=1\&language=en \&pcode=tsdpc320 $\underline{\text { \&plugin }=1}, 2016$ (accessed 18.04.16).

[34] MV. Gil, R. García, C. Pevida, F. Rubiera, Grindability and combustion behavior of coal and torrefied biomass blends, Bioresource Technology 191 (2015) 205-212.

[35] Canadian Biomass. Biomass Torrefaction Technologies. http://www.canadianbiomassmagazine.ca/content/view/2728/132/ ， 2011 (accessed 28.04.14).

[36] K. Onarheim, A. Mathisen, A. Arasto, Barriers and opportunities for application of CCS in 
Nordicindustry - A sectorial approach, International Journal of Greenhouse Gas Control 36 (2015) 93-105.

[37] S. Proskurinas, R. Sikkema, J. Heinimö, E. Vakkilainen, Five years left - How are the EU member states contributing to the $20 \%$ target for EU's renewable energy consumption; the role of woody biomass, Biomass and Bioenergy 95 (2016) 64-77.

[38] W. Stelte, Torrefaction of unutilized biomass resources and characterization of torrefaction gasses. Result at Kontrakt (RK) Report, Danish Technological Institute, 2012.

[39] K. Kuparinen, J. Heinimö, E. Vakkilainen, World's largest biofuel and pellet plantsgeographic distribution, capacity share, and feedstock supply, Biofuels Bioprod Bioref 8(6) (2014) 747-754.

[40] Solvay.com, Solvay launches production of torrefied biomass, a new solution that contributes to energy transition, http://www.solvay.com/en/media/press_releases/20140311Biocoal.html 2014 (accessed 28.09.16).

[41] Airex Energy. Industrial applications of solid biofuels carbonfx technology. CCRA, http://www.cancarb.ca/pdfs/pubs/Airex\%20CRA\%20-\%20Torrefaction\%20Bertrand.pdf ， 2012 (accessed 28.04.14).

[42] Diocarbon. http://www.diacarbon.com/, 2015 (accessed 28.04.15).

[43] W. van Swaaij, S. Kersten, W. Palz, Biomass power for the world, Vienna edition, volume 6 395-422.

[44] T. Ranta, J. Föhr, H. Soininen. Evaluation of a pilot-scale wood torrefcaction plant based on pellet properties and Finnish market economics, Energy and environment 7(2) (2016) 159168.

[45] P. Lamers, R. Hoefnagels, M. Junginger, C. Hamerlinck, A. Faaij, Global solid biomass trade for energy by 2020: an assessment of potential import streams and supply costs to North-West Europe under different sustainability constraints, GCB Bioenergy 7(4) (2015) 618-634.

[46] R. Hoefnagels, G. Resch, M. Junginger, A. Faaij, International and domestic uses of solid biofuels under different renewable energy support scenarios in the European Union, Applied Energy, 131 (2014) 139-157.

[47] EA. Abdelaziz, R. Saidur, S. Mekhilef, A review on energy saving strategies in industrial sector, Renew Sust Energ Rev 15 (2011) 150-168.

[48] D. Bradley, B. Hektor, M. Wild, M. Deutmeyer, P-P. Schouwenberg, JR. Hess, et al, Low Cost, Long Distance Biomass Supply Chains, IEA Bioenergy Task 40; 2013.

[49] G-A. Tsalidis, Y. Joshi, G. Korevaar, W. de Jong, Life cycle assessment of direct co-firing of torrefied and/or pelletised woody biomass with coal in The Netherlands, Journ of Cleaner Produc 81(15) (2014) 168-177.

[50] J. Li, X. Zhang, H. Pawlak-Kruczek, W. Yang, P. Kruczek, W. Blasiak, Process simulation of co-firing torrefied biomass in a $220 \mathrm{MWe}$ coal-fired power plant, Energy Conversion and Management 84 (2014) 503-511.

[51] Y-F. Huang, F-S. Syu, P-T. Chiueh, S-L. Lo, Life cycle assessment of biochar cofiring with coal, Bioresource Technology 131 (2013) 166-171.

[52] P. Basu, J. Butler M.A. Leon, Biomass co-firing options on the emission reduction and electricity generation costs in coal-fired power plants, Renewable Energy 36 (1) (2011) 282- 
288.

[53] Z. Liu, W. Hu, Z. Jiang, B. Mi, B. Fei, Investigating combustion behaviors of bamboo, torrefied bamboo, coal and their respective blends by thermogravimetric analysis, Renewable Energy 87(1) (2016) 346-352.

[54] Aeon Energy Solutions. Konza Renewable Fuels, http://www.aeonnrg.com/partner.aspx?partnerID=2, 2014. (accessed 8.05.14).

[55] J. Li, A. Brzdekiewicz, W. Yang, W. Blasiak, Co-firing based on biomass torrefaction in a pulverized coal boiler with aim of 100\% fuel switching, Applied Energy 99 (2012) 344-354.

[56] Clean Coal CenterProfiles, $\mathrm{CO}_{2}$ abatement in the iron and steel industry. IEA, http://www.iea-coal.org.uk/documents/82861/8363/CO2-abatement-in-the-iron-and-steelindustry,-CCC/193, 2012 (accessed 8.09.14).

[57] The green steel revolution: replacing fossil fuels in steel production. United Nations Environment Programme,

UNEP. http://www.unep.org/forests/Portals/142/docs/our_vision/Green_Steel.pdf ， 2013 (accessed 8.05.15).

[58] ULCOS. Ultra-Low Carbon dioxide $\left(\mathrm{CO}_{2}\right) \quad$ Steelmaking; 2015. http://www.ulcos.org/en/about_ulcos/home.php , 2015 (accessed 8.11.15).

[59] Fl. Smidth, Alternative fuels, Burning Alternative Fuels in Cement Kiln, http://www.flsmidth.com/en-us/Industries/Cement/Operation/Alternative+fuels+solutions , 2009 (accessed 8.08.14).

[60] JG. Mathieson, H. Rogers, MA. Somerville, S. Jahanshahi, P. Ridgeway, Potential for the use of biomass in the iron and steel industry, Chemeca 2011, Engineering a Better World, Australia.

[61] H. Suopajärvi, T. Fabritius, Evaluation of the possibility to utilize biomass in Finnish blast furnace ironmaking, In: 4th International Conference on Process Development in Iron and Steelmaking, Luleå, Sweden, 2012.

[62] M. Carvalho, C. Marcelo, E. Vakkilainen, Bio-SNG Production in Brazil: Applications in the Iron and Steel Industry, In: IX Japan-Brazil Symposium on Dust Processing, 2013.

[63] H. Suopajärvi, M. Iljana, J. Haapakangas, Biomateriapohjaisten ja vaihtoehtoisten raakaaineiden ja tuotteiden fysikaaliset ja kemialliset ominaisuudet, (BioMater-based and alternative raw materials and products, physical and chemical properties) 2013 [In Finnish]. Univerity of Oulu, Oulu.

[64] G. Fick, O. Mirgaux, P. Neau, F. Patisson, Using Biomass for Pig Iron Production: A Technical, Environmental and Economical Assessment. Waste and Biomass Valorizat 5(1) (2014) 43-55.

[65] C. Wang, P. Mellin, J. Lövgren, L. Nilsson, W. Yang, H. Salman, et al, Biomass as blast furnace injectant - Considering availability, pretreatment and deployment in the Swedish steel industry, Energy Conversion and Management 102(15) (2015) 217-226.

[66] H. Suopajärvi, E. Pongrácz, T. Fabritius, Bioreducer use in Finnish blast furnace ironmaking - Analysis of $\mathrm{CO}_{2}$ emission reduction potential and mitigation cost, Applied Energy 124 (2014) 82-93.

[67] H. Ljungstedt, D. Johanssonet, MT. Johansson, K. Karltorp, Options for Increased Use and Refining of Biomass - the Case of Energy-intensive Industry in Sweden, In: World 
Renewable Energy Congress 2011, Sweden 2011, 17-24.

[68] Andritz, pulp \& paper. A passion for innovation; 2015. http://www.andritz.com/pp-pulpand-paper/pp-research-development.htm, 2015 (accessed 12.05.2014).

[69] Nikkei Asian Review. Nippon Paper roasts its way into the renewable energy game, http://asia.nikkei.com/magazine/20160818-SONY-S-RENAISSANCE/Tech-

Science/Nippon-Paper-roasts-its-way-into-the-renewable-energy-game?page $=1 \quad$ (accessed 08.10.16).

[70] Nippon Paper Industries Group. Nippon Paper Industries develops new biomass solid fuel effective for reducing $\mathrm{CO}_{2}$ emissions biomass co-firing rate in existing coal fired boiler rises by an approximate factor of ten; http://www.nipponpapergroup.com/english/news/year/2013/news130403001304.html , 2013. (accessed 8.05.2015).

[71] P. Baijpai, Biorefinery in the pulp and paper industry, Amsterdam, Netherland; 2013.

[72] Tracking Clean Energy Progress 2013. IEA, http://www.iea.org/publications/tcep_web.pdf, 2013 (accessed 8.05.2015).

[73] J. Koppejan, S. Sokhansanj, S. Melin, S. Madrali, Status overview of torrefaction technologies, A Report to IEA Bioenergy Task 32; 2012.

[74] A. Fabio, C. Franck. Panorama 2012 - Petrochemicals and chemicals from biomass, IAEA INIS 43(39) (2011) 1-10.

[75] D. Johansson, PÅ. Franck, T. Berntsson, Hydrogen production from biomass gasification in the oil refining industry-A system analysis, Energy 38(1) (2012) 212-227.

[76] PNR. Vennestrøm, CM. Osmundsen, CH. Christensen, E. Taarning, Beyond Petrochemicals: The Renewable Chemicals Industry, Angewandte Chemie 55(45) (2011) 10502-10509.

[77] S. Proskurina, H. Rimppi, J. Heinimö, J. Hansson, A. Orlov, R. KC et al., Logistical, economic, environmental and regulatory conditions for future wood pellet transportation by sea to Europe: The case of Northwest Russian seaports, Renew Sustain Energy Rev 56 (2016) 38-50.

[78] S. Proskurina, J. Heinimö, M. Mikkilä, E, Vakkilainen, The wood pellet business in Russia with the role of North-West Russian regions: present trends and future challenges. Renew Sustain Energy Rev 51 (2015) 730-40.

[79] Opinion of expert in torrefaction technology.

[80] M. Svanberg, I. Olofsson, J. Flodén, A. Nordin, Analysing biomass torrefaction supply chain costs, Bioresource Technology 142 (2013) 287-296.

[81] R. Ehrig. Analysis of Environmental and Economic Aspects of International Pellet Supply Chains. PhD thesis, Technischen Universität Berlin, 2014.

[82] D. Agar, J. Gil, D. Sanchezc, I. Echeverria, M. Wihersaari, Torrefied versus conventional pellet production - A comparative study on energy and emission balance based on pilotplant data and EU sustainability criteria, Applied Energy 138 (2015) 621-630. 